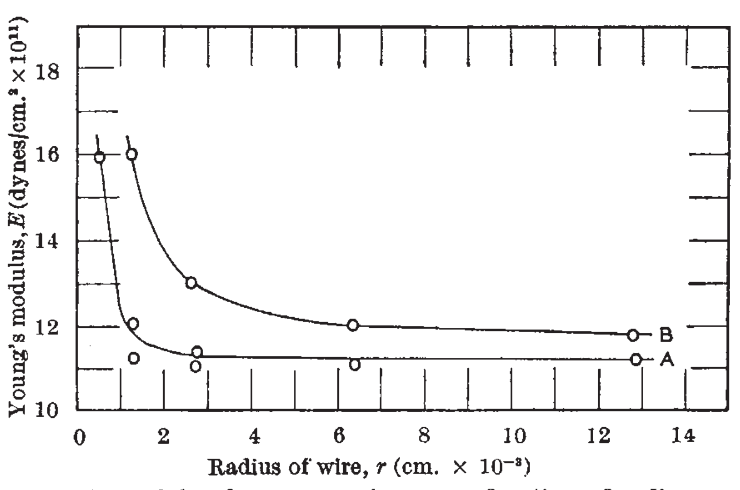

Young's modulus for copper wires as a function of radius $r$. $(A)$ Annealed wires; $(B)$ hard-drawn wire

approached. The amount of disorder due to the zonal texture, however, is very small and cennot account for the observed increase in the modulus of elasticity, which was as large as 50 per cent in our case. This, together with the fact that the simple, isotropic texture of tungsten does not exhibit any changes upon being drawn to a smaller diameter, indicates that the variations of Young's modulus with the wire diameter result from the increase of the [111] component of the texture during drawing. This change is not completely destroyed by annealing. From the relation

$$
\frac{1}{E}=\frac{X_{111}}{E_{111}}+\frac{X_{100}}{E_{100}^{1}}
$$

where $E$ is the observed Young's modulus and $X_{111}$ and $X_{100}$ are the fractions of crystals in the wire oriented in [111] and [100] directions respectively, one can roughly evaluate these changes in the texture. Thus, in annealed copper wires, the [111] component increases from 61 per cent to 88 per cent as the wire diameter decreases from $258 \mu$ to $10 \cdot 6 \mu$. In the case of cold-drawn wires, the same change is achieved with the wires drawn down only to $25 \mu$ diameter. Similar calculations could be made for nickel or platinum if their double textures were known.

George C. KuCZYNSkI

Massachusetts Institute of Technology,

$$
\text { Cambridge, Mass. }
$$$$
\text { Sept. } 20 .
$$

Phillips, A. J., and Smith, A. A., Proc. Amer. Soc. Test. Mat., 36, (2), 263 (1936).

'Barrett, C. S., "Structure of Metals", 457 (McGraw-Hill Book Co., Inc.)

3 Schmid, E., and Wassermann, G., Z. Phys., 42, 779 (1927).

4 Ettisch, M., Polanyi, M., and Weissenberg, K., Z. Phys., 7, 181 (1921)

${ }^{5}$ Jeffries, Z., Trans. Amer. Inst. Mech. Eng., 70, 303 (1924).

- Schmid, E., and Boas, W., "Kristallplastizitat", 202 (Berlin, 1935).

'Norton, J. T., and Kuczynski, G. C., Instruments, 21, 4, 328 (1948).

${ }^{8}$ Schmid, E., and Wassermann, G., Z. Metallk., 19. 325 (1927).

\section{Preparation of Methanol Labelled with Isotopic Carbon}

Perhaps the most important single step in the preparation of compounds labelled with $\mathrm{a}$ carbon isotope is the reduction of carbon dioxide to methanol. Three suitable methods for this purpose have been described, namely : (i) the hydrogenolysis of methyl formate ${ }^{1,2}$ (from formic acid prepared by reduction of carbon dioxide), (ii) the catalytic hydrogenation of carbon dioxide ${ }^{3}$ (at $285^{\circ}, 450$ atmospheres pressure), and (iii) the reduction of carbon dioxide by means of lithium aluminium hydride ${ }^{4}$. The latter method would appear to offer some obvious practical advantages; but we have shown that the purity of methanol so prepared leaves much to be desired.

The lithium aluminium hydride method requires the use of diethyl carbitol as solvent for the hydride and of butyl carbitol for effecting alcoholysis of the reduction product, $\mathrm{LiAl}\left(\mathrm{OCH}_{3}\right)_{4}$. We have found, however, that under the conditions of the experiment these solvents may decompose with the formation of ethanol and butanol respectively. As separation of methanol from such contaminants is difficult on the micro-scale, we have used solvents which cannot afford such volatile byproducts. The most satisfactory of these were tetrahydro-furfuroxy-tetrahydro-pyran (solvent for lithium aluminium hydride) and tetrahydro-furfuryl alcohol (for alcoholysis), the former being readily prepared by reaction of $\Delta^{2}$-dihydropyran with tetrahydro-furfuryl alcohol ${ }^{5}$.

The preferred technique for reduction of carbon dioxide was as follows. A $0 \cdot 8 \mathrm{M}$ solution of lithium aluminium hydride ( 2 equivalents) in the above. mentioned solvent was prepared under a blanket of nitrogen and was allowed to react with dry carbon dioxide from a reservoir ; absorption of the gas was always complete. Twelve equivalents of tetrahydrofurfuryl alcohol was added to the reaction mixture, which was then heated at $110^{\circ}$ under $60 \mathrm{~mm}$. pressure, to expel the methanol, which was stripped from the resulting distillate by normal vacuum technique, leaving a small residue of high-boiling liquid. The methanol was of high purity and contained only very small amounts of water, formaldehyde and tetrahydrofurfuryl alcohol. The results

\begin{tabular}{|c|c|c|c|c|}
\hline Substance & $n_{D}^{20}$ & $d_{4}^{20}$ & Impurities & Yield \\
\hline $\begin{array}{l}\text { (1) } \mathrm{CH}_{3} \mathrm{OH} \text { pre- } \\
\text { pared by use of } \\
\text { diethyl and } \\
\text { butyl carbitols } \\
\text { (2) } \mathrm{CH}_{8} \mathrm{OH} \text { pre- } \\
\text { pared by use of } \\
\text { solvents de- } \\
\text { scribed above } \\
\text { (3) Pure } \mathrm{CH}_{8} \mathrm{OH}\end{array}$ & $\begin{array}{l}1 \cdot 338 \\
1 \cdot 334 \\
1 \cdot 329\end{array}$ & $\begin{array}{l}0.82 \\
0.793 \\
0.792\end{array}$ & $\begin{array}{l}\text { Water, } \mathrm{HCHO} \\
\mathrm{C}_{2} \mathrm{H}_{5} \mathrm{OH}, \mathrm{C}_{4} \mathrm{H}_{9} \mathrm{OH} \\
\text { Water, HCHO } \\
\text { - }\end{array}$ & $\begin{array}{l}75-80 \% \\
\text { of } \mathrm{CH}_{3} \mathrm{OH} \\
\text { c. } 90 \% \\
\text { of } \mathrm{CH}, \mathrm{OH} \\
-\end{array}$ \\
\hline $\begin{array}{l}\text { (4) } \mathrm{CH}_{8} \mathrm{I} \text { prepared } \\
\text { from (1) } \\
\text { (5) CHs prepared } \\
\text { from (2) } \\
\text { (6) Pure } \mathrm{CH}_{8} \mathrm{I}\end{array}$ & $\begin{array}{l}1 \cdot 524 \\
\left(25^{\circ}\right) \\
1 \cdot 530 \\
1 \cdot 530\end{array}$ & $\begin{array}{c}- \\
2 \cdot 24 \\
2 \cdot 28\end{array}$ & $\begin{array}{c}\mathrm{C}_{2} \mathrm{H}_{6} \mathrm{I}, \mathrm{C}_{3} \mathrm{H}_{9} \mathrm{I} \\
\text { none } \\
-\end{array}$ & $\begin{array}{l}65-75 \% \\
\left.\text { (on } \mathrm{CO}_{2}\right) \\
77-85 \% \\
\left(\text { on } \mathrm{CO}_{2}\right) \\
-\end{array}$ \\
\hline
\end{tabular}
of comparative experiments are given in the table.

By means of a Zeisel reaction (followed by removal of iodine, hydriodic acid and water from the product), methanol was converted to methyl iodide in 77-85 per cent yield, based on the carbon dioxide taken. The methyl iodide so prepared was pure, as judged by physical constants and chemical analysis (found: I, 88.9 ; calc. for $\mathrm{CH}_{3} \mathrm{I}$ : I, 89.4 per cent).

The procedure described has been satisfactorily applied to syntheses involving the use of isotopic carbon atoms.

This note is published by permission of the Director of the Chemical Research Laboratory.

$$
\begin{aligned}
& \text { J. D. Cox } \\
& \text { R. J. WARNE }
\end{aligned}
$$

Chemical Research Laboratory, Teddington, Middlesex. Nov. 26.

1 Harman, Stewart and Ruben, J. Amer. Chem. Soc., 84, 2293 (1942). ${ }^{2}$ Melville, Rachele and Keller, J. Biol. Chem., 169, 419 (1947).

${ }^{3}$ Tolbert, $J$. Amer. Chem. Soc., 69, 1529 (1947).

'Nystrom, Yanko and Brown, J. Amer. Chem. Soc., 70, 441 (1948). s Woods and Kramer, J. Amer. Chem. Soc., 69, 2246 (1947). 